\title{
The Questions of Piracy in the Light of International Law and the Responsibility of a Failed State
}

\author{
HARKAI István ${ }^{1}$
}

\begin{abstract}
These days, one of the most significant issue is maritime piracy and armed robbery; it poses a high threat against international peace and security. These crimes can occur anywhere on the high seas, but the most infected areas are the western basin of the Indian Ocean, the Gulf of Aden, Southeast Asia, or the Gulf of Guinea, where piracy causes many troubles to world trade. The crime of piracy calls for a strong and substantive answer. In this paper, the author tries to look for legal and non-legal devices against piracy and tries to give an answer to the question whether we can take a failed state to account in international law?
\end{abstract}

Keywords: Somalia, piracy, jurisdiction, responsibility, failed state

\section{Introduction}

The most infected territory for pirate-activity is the so-called Horn of Africa, namely the Gulf of Aden, and the western basin of the Indian Ocean, but robbers are present at the coast of Southeast Asia, and significant pirate activity is evolving in the Gulf of Guinea.

The owners of vessels attacked by maritime bandits and the Flag States try to act against piracy and attempt to drive back and discourage these activities. The efforts against Somali pirates have been significantly successful. The act of piracy is one of the oldest "professions" in the world caused by deep-rooted social and political problems. This is the reason for the international community not being able to eliminate the international crime of piracy and armed robbery despite all the endeavors to heal the causes, yet these have not been enough to permanently abolish piracy.

\section{History of Piracy and Maritime Robbery}

History of crimes committed on seas and commercial shipping were born in the same age. The so-called Sea Peoples ravaged the coast of the Eastern Mediterranean in the $14^{\text {th }}$ century before Christ. [1] Merchants of ancient Greek city-states were exposed to looting on the Aegean Sea. Plutarch also urged actions against maritime bandits and emphasized that the coastal state could only claim supremacy over the part of the sea belonging to its authority if the Greek states establish security. [2] Not all Hellenic citizens considered pirates offenders. Hieronymus of Cardia designated pirate-activity as an "honorable entrepreneurial activity", where pirates are mercenaries, brothers-in-arms. [3]

1 dr. jur., e-mail: harkai.istvan89@gmail.com 
The security of sailing was an important strategic issue in the Roman era as well. According to Strabo, the historian-geographer with Greek descendants, two types of groups existed. One of them was a civilized one and used the seas for peaceful purposes. The other one was a group of barbarians, who committed various misdeeds. [4]

On the eve of the Great Migration, Goth invaders pillaged along the seashore of the Black Sea, and reached Crete and Cyprus. Franks and Germans harassed the trade routes on the North Sea. Patrick the monk was abducted by Celtic pirates from Wales and dragged to Ireland. Later he was revered as a saint. [5]

The Vikings were the most notorious maritime raiders in the Middle Ages. They bothered not only the coastal regions but internal lands as well. They gladly marched deep inside the attacked countries using rivers as water roads. [6] Byzantine territorial waters were threatened by the expansionist Arabic sailors. The Byzantine Empire had quite a developed legal system. In the Rhodian Sea Law (Lex Rhodia), the rules of commerce, navigation and defense against pirates were collected. [2]

The real golden age of piracy was in the $16-17^{\text {th }}$ century. In this era not only the so-called Jolly Roger, the characteristic pirate flag was born, but the three main types of piracy - privateers, buccaneers and corsairs - as well. The "authentic" pirates belonged to the first category. They were authorized by their ruler, who gave them the so-called letter of marque, to attack hostile vessels. The buccaneers were organized and controlled from the bases on the West Indies. The corsairs were Muslim robbers of the Mediterranean Sea in the $16-19^{\text {th }}$ centuries. Their headquarters were located in Algiers, Tunis, Tripoli and Morocco on the north coast of Africa. They were also authorized to attack Christian sails. Their Christian opponents were the Corsairs of Malta. The grandmaster of the Knights of Saint John allowed them to raid the Muslim ships. [6]

The golden age of organized piracy ended in 1816 with the bombing of Algiers, in Southeast Asia pirate activity was defeated by the Ducht, while on the South China Sea it was defeated by the English fleet. Naval powers banned the issue of letters of marque and proscribed the privateers in the Declaration of Paris in 1856. [6]

\section{The Term Piracy}

If we would like to define the modern term piracy, we have to invoke Article 100-107 of the Convention on the Law of the Sea, which was accepted in 1982. [7] The term is consuetudinary and not every country has joined to the United Nations Convention on the Law of the Sea (UNCLOS) Treaty of Montego Bay. [8]

The modern definition has many antecedents in legal history. It is a basic fact that the offenders of such a crime have to be considered hostis humani generis, the enemies of mankind. Because they are beyond legal protection, each and every person is allowed to act against them. [9] Ancient Greek sources created the first terms for the trading people of the eastern Mediterranean in the $2^{\text {nd }}$ century BC; that was the peirato. Romans used a similar word, peiraton, which meant free sailors who stood apart from the scope of the law. [10] The famous orator and jurist consul Marcus Tullius Cicero alleged that the pirates are enemies of every community. [10] 
Among the scientists of the late Middle Ages ${ }^{2}$ John of Trevisa, a teacher at the University of Oxford in England was the first, who translated the word piratae as "see theves (sea thieves)". [10]

In the $17^{\text {th }}$ century, English and Dutch legal literature dealt in depth with the "pirate-question". According to the definition of Cornelis van Bynkershoek, pirates are the ones robbing on the high seas and looting on the mainland without the permission of a sovereign power. In the terminology of Charles Molloy the pirates are sea rovers, enemies of the entire human race. They confront not only mankind, but they act against a specific state as well. Later on, legal experts extended the terminology with aggressiveness and robbery. [9]

During the development of the English legal definition of piracy, the term gradually extended with elements from the field of criminal law. First, we have to mention criminal intent, so the straight intent (doluc directus) of the pirates has to be directed at asportation (felonious removal) of the attacked ships and the possessions shipboard. ${ }^{3}$ When two opposing hostile states loot each other's ships, it has to be considered sea robbery. However, it is obviously not piracy, because in a state of war plunder is allowed. Dozens of such acts occurred during the American Civil War or in World War II. [11]

The protected legal interest is not only the protection of property, but also, the peace of mankind as well, [9] the order and peace of the high seas. [9]

The first attempt of the codification of piracy made by the Committee of Experts of the League of Nations was in 1926. In 1930, the $22^{\text {nd }}$ Article of the London Naval Treaty extended the rules, regarding submarines. Until 1956, there was a debate on the question whether naval ships could commit piracy, when the International Law Commission of the UN brought the debate to an end, declaring, "piracy could only be committed by privately owned ships, not by warships." [9]

Codifiers of the $20^{\text {th }}$ century argued about the unlawfully appropriation. From their point of view, it was not necessary to ascertain the guiltiness that the intention of pirates cover the animus furandi because the motivation for crime could be anything else, for example hatred or vengeance.

The first declared terminology of piracy appeared in the $15^{\text {th }}$ Article of Convention on the High Seas in 1958. This definition is confined to the private acts, which were committed against private ships. [12] The Agreement of Nyon from 1937 gives us a wider expression when considering submarines as surface warships. [9]

The 1982 UNCLOS Treaty integrated the rules of the Treaty of 1958 and its developments into a single frame. But there was no common denomination in two important questions. One of them was the animus furandi, the question of private interest, the other one was the place where the crime was committed, the high seas, because the coastal water is under the criminal jurisdiction of the coastal state, where the act could only be considered piracy if the criminal law of the state contains the statutory definition of piracy. ${ }^{4}$

2 In the Middle Ages contemporary languages referred to the sea robbers according to their nationalities, so for example the Vikings, who committed many of pirate acts. English resources used the term Dani piratae for the first time in the $14^{\text {th }}$ century.

3 Sir Matthew Hale, Sir Edward East, James Kent.

4 This is mainly relevant in case of Southeast Asia, because most of those crimes which were committed in the region occurred on the coastal waters. 
HARKAI István: The Questions of Piracy in the Light of International Law and the Responsibility...

The Article 101 of UNCLOS Treaty classifies the following acts as piracy:

Piracy consists of any of the following acts:

a) any illegal acts of violence or detention, or any act of depredation, committed for private ends by the crew or the passengers of a private ship or a private aircraft, and directed:

i) on the high seas, against another ship or aircraft, or against persons or property on board such ship or aircraft;

ii) against a ship, aircraft, persons or property in a place outside the jurisdiction of any State (...). [13]

Moreover, the norm knows the formation of incitement, but it does not consist of the attempt of a crime, which is considered by the legal practice materialized when the act entered into the period of attempt. The preparation is also missing.

The crime of piracy is a sort of "opened statutory definition", because felony, which is hurting the protected legal interest, could be realised in countless ways, not to mention that the intention of asportation is not declared squarely, so the effect of the crime and the time when the legal interest is harmed is unclear.

The term of high seas as a place of committing the crime should not form a subject of a debate, because it is clear that the crimes committed on coastal waters exclusively belong to the jurisdiction of the coastal state, while the high seas, which are res communis omnium usus, fall under universal jurisdiction.

\section{The Types of Piracy}

The first and easiest mode of attack is when pirates step on board a ship (boarding), plunder the crew, and then leave. In the second case, pirates deprive the crew of their properties, and then take the whole cargo. Sea robbers ambush vessels in the early morning hours with well organised, 6-7 - occasionally more (even 70) - membered-armed groups. The mother ship with an advanced navigation system carries the equipment and the fuel. The bandits approach the target with powerboats and climb up on the stern. The so-called phantom ships belong to the third type. Pirates take not only the cargo, but also the vessel with the whole crew on it. After this, they sell the cargo and ask ransom for the hostages. The stolen ship will be repainted, renamed and re-catalogued in a foreign country. [14]

According to the definition of the International Maritime Organization, there are more specific differences as well. We can make a distinction between common piracy and political piracy. [15] Common piracy is when pirates attack a vessel only for the sake of private interests. These are the so-called low-level armed robberies, which are brought to effect near the seashore; the bandits use boats and cold weapons or small caliber handguns. The medium-level armed assault and robbery is escorted by a mother ship and committed by well-armed pirates. The "capital crime" is the "major criminal highjack", the hijack of the attacked ship. To carry out this type of attack, sea thieves need detailed plans, ample resources, trained and armed attackers, and last but not least, land management. [15]

Political piracy is founded on political purposes and motivations; the intent of gaining profit is only a subsidiary option. These actions are rather committed by groups, which are linked to terrorist organizations. [15] 
HARKAI István: The Questions of Piracy in the Light of International Law and the Responsibility...

Nevertheless, we can identify interesting connections between the two categories. The two big Somali Islamist rebel groups, Al Shabab and the Hizbul Islam are in rapport with the lords of pirate-companies, who support them from the abundant prizes coming from pirate-activity. ${ }^{5}[15]$

\section{Causes of the Phenomenon}

Primarily, piracy is a "subsistence" crime. Attacks are committed by residents of regions where the population lives in relative poverty. In addition, the closeness of the sea is also a basic condition. Pirates need headquarters and supplies, which can easily be provided by the population of the coastal area.

But why exactly has Somalia has become Tortuga, a "pirate paradise", in the last decade? We can answer this question with three quite simple arguments. One of them is the geographical location of Somalia, which is situated on the Horn of Africa, in a perfect geostrategic position, which makes it easier to control the area, or at least collect pieces of information about the merchant convoys sailing along the Somali coasts. The other reason is anarchy. It is beyond dispute that Somalia is a failed state, without administration of justice. However, if there were some kind of central jurisdiction, it could restrain criminal activities. This statement is demonstrated by that six-month period when the Islamic Courts practically abolished piracy, but when the Islamist government fell, sea bandits reorganized themselves and the attacks continued. [16]

Somalia is characterized by political instability; the federal government is only able to control the capital, Mogadishu. Two thirds of the young population is unemployed, the households have to live on only two dollars per day. [17] The whole population is dependent on the international food supply, which is more than 150 tons every year. Regrettably, international aid shipments are popular targets of the pirates. [17]

After the long civil war, ${ }^{6}$ since 1991, on the coastal waters - lacking Somali coast guards - the main European, Asian and African companies started to exploit and pollute the coastal waters. The Somali people, deprived of their livelihood, tried to protect themselves as much as they could, so the first pirates came from among the fishermen who knew the surrounding waters well and were familiar with navigation. [17]

Later on, a significant part of the coastguard joined the fishermen. In a short period of time, the little groups formed into small clans with a hierarchy. The clans from the region near Kismayoo recognize the primacy of the clans of Harardheere and Hobyo. [16] The clans are independent of tribal and ethnic bonds; it is hard to guess their membership.

In one band, around 50 members can be found, and there are some groups with Pakistani and Bantu fishermen. [16] The "pawns" are the local fishermen who support the actions with their local knowledge. The "bishops" are the former militiamen, they are competent in the use of weapons, and they execute the attacks or defend the bases on the mainland. The "chess masters" are the engineering and planning experts who gain dates from the databases of freighter companies and work out the details of the missions. [16] The pirates have moles in positions of authority who receive money from the ransom in lieu of the valuable pieces of information leaked by them. [17]

5 Occasionally we can detect some similarities between piracy and terrorist acts committed on sea in the light of perpetration. Politically motivated rebellions and uprisings also take after the crime of piracy.

6 Which was followed by a serious poverty demanding at least 200 thousand lives. 
The clans have built up quite a developed heartland from the rich spoils; they are continuously upgrading their technology. [17] It is a curiosity that a pirate "stock exchange" runs, where the spoils are sold and people can make investments, which can be useful in pirate activity. Once a woman who received an RPG rocket launcher as alimony, sold it on the market for 75 thousand dollars. [17]

Pirate activity seriously redounds in the GDP of Somalia. ${ }^{7}$ This is so true that - in the African context - piracy provides a relatively high standard of living not only for the pirates and warlords of the clans, but for the average people as well. [18] The most seductive fact for pirates is not really the value of the stolen goods, but rather the ransom given in return for the hostages. [16] Members of an attacking team could earn around 30 thousand dollars per capita. Much more money goes into the pocket of the leaders of clans. Participants of a particular attack could receive even $30 \%$ of the ransom, the militia defending the pirate haunts take $10 \%$ in return for their service, and last but not least, the local community also obtain in planty (around 20\%). 20\% is the reinvestment in the "pirate venture". 10\% goes into the pocket of Al-Shabab, which refers to a real connection between pirate companies and terrorist organizations. ${ }^{8}$ [16] Not only the Somali Al-Shabab or Hyzbul Islam are related to pirate clans, but probably Al-Kaida is also connected to them and receives financial support for the attacks on different targets. [19]

The relationship between pirates and terrorists is pretty paradoxical. As I have already mentioned the Islamic courts declared jihad against sea robbers and extinguished piracy in the past. Nevertheless, in the last couple of years, after the fall of the Islamist government, the activity has been renewed and is flourishing; although Sharia still prohibits abduction, punishing hostages or piracy itself. [20] Another interesting fact is that, usually, pirates do not follow any kind of religious or political ideology; but instead, making profit is their main purpose. This fact also emphasises the difference between terrorists and pirates. [20]

The main seat of pirates used to be the port of Mogadishu and its outskirts. Later on, it moved to Puntland, then further into the region of the Gulf of Aden. Puntland ${ }^{9}$ is a separatist province of the collapsed Somalia, which was created by the Clan Harti in 1998. [21] The "province-state" has a relatively stable government. Puntland is the biggest citadel of piracy and receives the highest share in the profit of crimes committed on the seas.

Pirates try to explain and translate their acts into the language of international law. Apart from the fact that they consider their acts as a retributive mission against the Western and Asian ships fishing and polluting the sea in an unlawful way, Somalia does not acknowledge the effective and valid rules of the international law of the sea. Instead, they presume that the zone of influence spreads out 200 sea miles from the coastline, the ships sailing across the Somali waters have to pay "duty", but they regularly miss it, so the supposed premise of the pirates is completely legal. ${ }^{10}$ The name of the two biggest clans shows us how seriously this previous statement was meant by pirates. The biggest company is the Somali Marines from Eyl, Puntland, which refers to itself as the "Defenders of Somali Territorial Waters." The

7 Apart from the oil, because the exploitation is slowed due to the civil war, and also apart from fishing, where the biggest importer is Yemen. Since the beginning of the civil war, fish export has drastically fallen.

8 The Muslim political movements acted against pirate activity, they captured some pirate haunts, but they were not able to cross the boarders of Puntland. Today they live side by side respecting each other.

9 The territory of the province is 212 thousand $\mathrm{km}^{2}$, the population is almost 4 million.

10 The second approach is shown in the film drama Captain Phillips directed by Paul Greengrass in 2013, which is based on a true story. 
other grouping is the "National Volunteer Coast Guard", the headquarter of which is located in Kismayoo. [21] On the level of communication, the government of Puntland promised that it would act hard against piracy, but they would never abandon a profit-productive "branch". Moreover, warlords from Puntland also maintain pirate-militias. [21] In addition, foreign "financial circles", "business groups", and even some members of the federal government benefit from the "profit". [19]

The social influence of piracy is reflected in the fact that the local residents esteem pirates as defenders of their country confronting the exploiting powers. The clans pay a dividend to the local leaders and finance communal investments. [22] From the rest of the money, there is plenty for alcoholic beverages and for a special narcotic herb, the khat chewed during action.

\section{Defense beyond Law}

In the history of piracy, the world-powers used the devices of diplomacy, paid protection rackets, made contracts, and as a final solution used armed force against pirates. Until the end of $18^{\text {th }}$ century, the Knights of Saint John of Malta kept up a convoy service against the corsairs of North Africa. [23]

Since Somalia is not able to counteract effectively, the most obvious solution is that the freighters prepare themselves against pirate attacks. [24] It is hard to climb up the higher stern or sidewall and the captains can create waves with maneuvers to capsize the boats. They can install water cannons, barbed wire, electric fences, or they can employ armed guards. [22] The expenses for defenses make freight transport more expensive. According to some estimations, pirate activity causes 18 billion dollars loss each year for the world economy. [20]

It would be a more effective method if the vessels formed convoys escorted by warships. The ships are in continuous connection with American, British or other naval forces. Besides, there is a protocol in case of a pirate attack, which has to be followed in danger. The increase of military presence is the best practice, but it is only enough to heal the symptoms, it does not solve the whole problem.

Somali territorial waters are primarily used by European, American and Asian traders, thus NATO and the European Union have a prominent role. NATO has two permanent maritime groups, one of which is the so-called Standing NATO Maritime Group. [25]

NATO actions are granted not only on a conceptual level, but also have won political formulation during the informal meeting of defense ministers in Budapest in 2008, where the naval units of NATO got a mandate for the protection of vessels of the World Food Programme. [25] Man-of-wars of the participant states provide not only armed attendance, but also, they execute patrol on the neighbouring waters with Somalia as well. [25]

As the biggest supporter of Somalia, the European Union would like to ensure the safe and certain arrival of its aids; therefore, they established the military coordination action programme (NAVCO) [26] whereby naval units were installed on the threatened waters of the Indian Ocean and the Gulf of Aden. [25] In November 2008, a joint military operation was launched by the EU, under the codename Atalanta EUNAVFOR Somalia, [27] with more than 20 ships and fighters and a 1800 member crew. [25] Although Hungary does not have sea forces, it delegated an IT non-commissioned officer assisting in the mapping of attacks. ${ }^{11}$ [18]

11 Four other soldiers take part in the training of Somali governmental forces. The Training Mission was started by the NATO. [18: 34] 
There is no worthwhile international military co-operation without Americans, who created three several battle groups for the defense of shipping routes. The mission covers 1.1 million square miles; its duty is to act against the bandits, to facilitate global maritime security and the freedom of navigation. [25]

The pirate activity substantially aims at the most profitable oil carriers. After hijacking the biggest Saudi tanker, one of the biggest oil exporting countries, Saudi Arabia joined the international co-operation. The Saudi foreign secretary labeled the pirates as "disease need to be exterminate." [19]

\section{Legal Defense}

The United Nations labeled Somali piracy as a threat against international peace and security, thus based on universal jurisdiction, all of the states are entitled and obliged to act against piracy, as long as its legal system defines and punishes the crime of piracy. [8] These crimes are so very dangerous for society that it endangers the whole international community. Even if the acting state has no territorial, national or any other special jurisdiction, it is allowed to act against these offences. [28] Piracy and war crimes traditionally belong to this category of delicts. [29]

The text of UNCLOS Treaty disposes that states are allowed to act based on universal jurisdiction even on the high seas or the territory of the state, but this second option raises the question of harming sovereignty. It is a fundamental principle that every state has the right to proceed against its own citizens on its own territory according to its own law in the light of its own criminal law supremacy. Every other state is obliged to avoid breaching these rights. Chasing and arresting Somali pirates on the coastal waters or on the main land certainly infringes the sovereignty of Somalia unless it consented to the infringement. The principle volenti non-fit injuria excludes illegality. The permission has to be based on free will and it has to be given by a governmental body or person. [30] Somalia has made this kind of declaration when entering into agreement with the EU.

Aggression against pirates raises further questions as well, because by the $21^{\text {st }}$ century the prohibition of the use of armed forces is generally accepted. Since piracy falls under special judgment, the use of armed forces is permitted. [8] Especially since the UN Security Council declared pirate activity as a threat against international peace and security, it makes Chapter VII Article 43 of UN Charter applicable. This rule gives permission to use armed force or duress, but it is necessary to have the acceptance of the "host" state, which was given by Somalia in 2008. [25]

In the light of the above mentioned, international missions are allowed to intrude into Somali territorial waters, patrol and halt the suspicious watercraft and arrest their crews. [25] The procedure has to be necessary and proportional. [8] Combat against sea robbers mean law enforcement operations, where the classic rules of martial law are not applied, because these are not military actions among states. [9] This statement is only true for the cases occurring on international waters, on the main land the Geneva law could be applied, because the pursuer state is performing operations on the territory of another state, which refers to Article 2 of 1949 Geneva Convention. [8] 


\section{Questions of Responsibility}

Criminal jurisdiction could be based on the territorial principle, which is the place where the crime was committed. [29] According to the principle of nationality (or active-personality/ nationality of offender's principle) [29] against a Somali citizen, only Somalia is allowed to act. However, among pirates we can not only find Somali thieves, but for example Pakistani ones as well and the Somali authorities do not have the assertion of a right to act against them.

The nationality of the ship, which was the instrument of the crime, also creates a problem. Article 91 of UNCLOS Treaty says "ships have the nationality of the state whose flag they are entitled to fly. There must exist a genuine link between the state and the ship." [29] According to the passive personality principle, a state has jurisdiction over the offender of those crimes, which impact the citizens of the state in the past or in the future. [29] The principle of protection authorizes the state to exercise jurisdiction over those offenders who are not the citizens of the state, but violate or endanger the security of the state with their action. [29]

Establishing individual criminal responsibility of pirates would be the duty of Somalia in the first place, but at the moment, a central power able to bring the offenders to justice, does not exist. [25]

In most cases, the countries giving effect to the duress on pirates do not want to account for pirate activities before their own courts, so the international community sought a kind of solution, which could give effect to criminal sanctions.

The Djibouti Code of Conduct, which was accepted in January 2009, prescribed joint actions, information exchange for the participant Eastern African countries. Moreover, it consists of rules of investigation and prosecution. Furthermore, the Code prescribes that the plaintiffs of pirate acts have to be accommodated properly and the authorities have to promote their return home as soon as possible. [25] For financing the commitments, the participant states established funds and assistant offices. [8]

The most dedicated to calling pirates to account is Kenya. Under the agreements with the United States, Great Britain, the European Union and China, Kenya takes over and conducts procedures against the pirates who were arrested by international joint operations, in turn for the partners assisting in the modernization of the prison network and the administration of justice. [8]

Besides Kenya, the Seychelles made similar contracts, but the insular state asked a higher price of the EU than Kenya - complete financial, personal, logistic and infrastructural support. [25]

Passing over pirates could be operable, and indeed, it is operable, because numerous sentences have already been adjudicated, which are currently under execution, even if they are raising doubts. According to the UNCLOS Treaty, if a warship captures a pirate, the flag state has jurisdiction over the arrested sea robber. On the other hand, there is no expressis verbis prohibition in UNCLOS Treaty regarding the deliverance of pirates to a third state; however, it does not permit it pronouncedly. [8] 


\section{Is Somalia Responsible for the Pirate Activity?}

During the codification of the international legal responsibility, the International Law Commission of the United Nations endeavored to pass comprehensive regulations among the international community. The complete draft elaborated the consuetudinary standards, and although it does not have binding force as a treaty, it does have a basis of reference without doubt. [30] According to the Crawford draft, any unlawful or wrongful act of a state raises international legal responsibility if it is imputable and injures the international commitments of the state. [30] The injury could be the harm of jus cogens norm itself or could offend the interests of another states, business organizations or individuals.

The offending act could be proactive behavior, or omission. Because piracy is counteractive to international law, the state where such crimes are regularly committed has to do everything possible in order to stop criminal activity. Thus Somalia has legislative and law enforcement liabilities, at least theoretically. Practically there are three options to establish responsibility for Somalia for pirate activity. Firstly, if the infringement is imputable to the legislative power: for example, if the Federal Parliament of Somalia made a law, which would legitimate piracy that would be against international legal norms. On this ground - apart from the fact that Somalia has a different legal opinion about the maritime zones belonging to its sovereignty - the federal government, recognized by the international community, shall not be responsible, because as far as their power allows it, they try to prosecute the crimes committed in the country or on seas.

The case of the Somali coast guard is even more interesting. This armed force, which is responsible for the security of the Somali coast, belongs to the Somali executive power, and its function is to act against sea bandits. But it hardly does its duty (infringement carried out by omission), moreover, it is involved in pirate actions on the most infected coast lines, which would establish state responsibility, not to mention that pirate clans refer to themselves as voluntary coast guards, but of course, this does not mean that they are acting in the name of the federal government.

\section{Is Somalia a state at all?}

According to the current status of international law, the answer to this question is definitely "yes". Somalia has all the criteria in order to be recognized as a state. It has territory, [30] which is suitable for human life, it has population, [30] which means that there are people living there permanently, and they are linked to the state with a nationality or another status. In addition, it is necessary to have an independent governing power. [30] A plus condition is recognition, which might be constitutive or declarative. [29] Recognition is an objective factual situation (the fulfillment of the three conditions at the same time); it is when the international community acknowledges the three criteria together, of course spiced with a huge amount of the great power's politics.

But the existence of a state is not only a moment fixed by the law. It has not only criteria, but periods of existence as well. A state can come into existence and also, it may cease to exist. The cessation of a state has also different types, from fusion to division. [29] In my opinion, in the case of Somalia, we are talking about this latter version. After becoming 
independent of the colonial rule and being recognised by the international community, the former British and Italian Somaliland simply divided among the clans of the Somali nation, and the international community has not responded to this on the level of law, yet. Therefore, Somalia, as it is legaly recognised today, is only a legal fiction, in fact, it does not exist. [30] Therefore, because it is a failed state, which means not able to fulfill the requirements of the minimum criteria of a state, Somalia shall not be responsible for the violation of the international law.

Considering Somalia as a failed state makes it harder to challenge Somalia for the violation of international law, and makes it easier to understand the whole "pirate story" and the "state" system. Somalia was the first with 113.9 points with Very High Alert on the list of Failed States Index [31] published by Found for Peace in $2013 .{ }^{12}$ Somalia is the most referred to example of a failed state, because it fulfills all the conditions. Its government is not able to control the whole territory and maintain the administrational system efficiently, the majority of the population does not recognize its legitimacy. It is incapable of providing the basic public needs, and it does not have singular power over the enforcement agencies. [33]

In order to reach the phase of failure, the existence of internal war and insurgency, ethnic or religious conflicts is essential. After the collapse of the administration system and the infrastructure, the remains of the state have to face humanitarian disaster, the flood of migrants and poverty and most importantly, total economic deterioration. [34] The failure of a state has different phases, too. However, getting from a stable or a strong phase into a failed status also has an effect on international peace and security.

Somalia, as a recognized country by the international community, practically does not exist. The country has been replaced by clans, which have created and consolidated their own territories (Puntland, Somaliland, etc.) after the long civil war. These regions are practicing authority as a quasi state. Due to the militias, relative peace reigns, but for the time being they have not succeeded in building an operable, self-supporting state. There is a chance for Somalia to form a federal state in the future, which is the purpose of the independent regions in the long run, but there is no agreement as to the solution.

The deeper and deeper integration of piracy into the society, the tough struggle of AlShabab, the immeasurable corruption and the lack of raw materials make the situation more and more complicated.

\section{Summary}

Piracy is a phenomenon that can be proved since man first ventured onto the seas to sail. There has been no success in finding an effective remedy. On the coasts of the high seas, there will always be underdeveloped regions, which will not be able to maintain public order and control their territories and population properly. The international crime of piracy is well defined, acting against it is assured. As a failed state and the biggest citadel of piracy and in the long run Somalia will not be able to prevent piracy or call the pirates to account, even if its international legal responsibility was established.

12 Hungary is on the $141^{\text {th }}$ place with 47.6 points in the Stable category. 


\section{References}

[1] HÓMAN B., SZEKFÜ Gy., KERÉNYI K.: Egyetemes történet. Budapest: Magyar Szemle Társaság, 1935-1937. (Hóman Bálint munkái, digitális kiadás: Arcanum Adatbázis Kft., 2003.) http://mek.oszk.hu/07100/07139/html/index.html (downloaded: 2501 2014)

[2] CSATLÓS E.: A római kor és a középkor tengerjoga. De iurisprudentia et iure publico, VI 3 (2012).

[3] SOUZA, P. de: Piracy in the Graeco-Roman World. Cambridge: Cambridge University Press, 1999. http://catdir.loc.gov/catdir/samples/cam032/99013647.pdf (downloaded: 2501 2014)

[4] SOUZA, P. de: Ancient Rome and the Pirates. History Today, 517 (2007). www.historytoday.com/philip-souza/ancient-rome-and-pirates (downloaded: 2501 2014)

[5] MARITIME CONNECTOR: History of Piracy. http://maritime-connector.com/wiki/historyof-piracy (downloaded: 2501 2014)

[6] NATIONAL MUSEUM OF THE ROYAL NAVY: Piracy - A Brief History of Piracy.

Portsmouth, 2002. www.royalnavalmuseum.org/info_sheets_piracy.htm (downloaded: 2501 2014)

[7] United Nations Convention on the Law of the Sea - UNCLOS - 1982. www.un.org/depts/ los/convention_agreements/convention_overview_convention.htm (downloaded: 2501 2014)

[8] LATTMANN T.: A szomáliai kalózkodás kérdése a nemzetközi jogban és azon túl. Nemzet és Biztonság, 9 (2010), 66-75.

[9] VARGAA. F.: Kísérletek és eredmények a kalózkodás bűncselekményének definiálásában. Hadtudományi Szemle, VI 1 (2011), 30-43.

[10] RUBIN, A. P.: The Law of Piracy. Newport, Rhode Island: Naval War College Press, 1988.

[11] KAJTÁR I.: C.S.S. „Alabama” - Adalék a tengeri háborúk jogtörténetéhez. Jura, VI 1 (1997), 14-20.

[12] Convention on the High Seas - 1958. https://treaties.un.org/Pages/ViewDetails. aspx?src=TREATY\&mtdsg_no=XXI-2\&chapter=21\&lang=en (downloaded: 2501 2014)

[13] A MAGYAR KÖZTÁRSASÁG KORMÁNYA: H/5558. számú országgyülési határozati javaslat az Egyesült Nemzetek Montego Bayben, 1982. december 10-én aláírásra megnyitott Tengerjogi Egyezménye megerösitéséröl, valamint XI. részének végrehajtásával kapcsolatos, New Yorkban, 1994. július 24-én aláirásra megnyitott Megállapodáshoz történö csatlakozásról. www.parlament.hu/irom36/5558/5558.htm (downloaded: 1702 2014)

[14] McDANIEL, M. S.: The Serious Problem of Modern High Seas Piracy. Chicago, 2000.

(Presentation).www.cargolaw.com/presentations_pirates.html\#type_attacks (downloaded 02 02 2014)

[15] GRAF, A.: Countering Piracy and Maritime Terrorism in South East Asia and off the Horn of Africa. PiraT-Working Papers on Maritime Security, 5 (2011).

[16] BESENYÖ J., KISS Á. P.: Kelet Afrika tengeri farkasai - A szomáliai kalózok fénykora. Afrika Tanulmányok, 3-4 (2009), 46-58.

[17] MARSAI V.: A szomáliai kalózok és az EU Atalanta-missziója. Nemzet és biztonság, IV 4 (2011), 66-76.

[18] BESENYÖ J.: A szomáliai stabilitás és a nemzetközi közösség. Afrika Tanulmányok, V 1 (2011), 29-41. 
HARKAI István: The Questions of Piracy in the Light of International Law and the Responsibility...

[19] BESENYÖ J.: A szomáliai kalózkérdés: Milyen érdekek mentén? Mediterrán Világ, 13 (2010), 43-79.

[20] KIS Á. P., BESENYÖ J., RESPERGER I.: Országismertető Szomália. Második, bővített kiadás. Budapest: Honvéd Vezérkar Tudományos Kutatóhely és MH GEOSZ, 2014.

[21] RAVASZ Á.: Kalózkodás Szomáliában: Puntland és a bukott államiság. Kül-Világ, V 3-4 (2008), 86-104.

[22] FÁBIÁN É.: A francia haditengerészet Afrika szarvának kalózvizein. Nemzet és biztonság, IV 1 (2011), 18-27.

[23] KAJTÁR I.: A Mediterránum tengerjogának történetéhez. Jogtörténeti szemle, VI 4 (2004), 71-77.

[24] INTERNATIONAL MARITIME ORGANIZATION: Ship Protection Measures. (Section 8.) In. Piracy and Armed Robbery against Ships in Waters off the Coast of Somalia - Best Management Practices for Protection against Somalia Based Piracy. London, 2011. www.imo.org/MediaCentre/HotTopics/piracy/Documents/1339.pdf (downloaded 1702 2014)

[25] VARGA A. F.: Nemzetközi küzdelem a szomáliai kalózkodás ellen. Hadtudomány, Elektronikus szám (2011). www.mhtt.eu/hadtudomany/2011/2011_elektronikus/2011_e_14.pdf (downloaded 1702 2014)

[26] COUNCIL OF THE EUROPEAN UNION: Council Joint Action 2008/749/CFSP of 19 September 2008 on the European Union Military Coordination Action in Support of UN Security Council Resolution 1816. (EU NAVCO). Official Journal of the European Union, L 252/39 (2008). http://eur-lex.europa.eu/legal-content/EN/TXT/ HTML/?uri=CELEX:32008E0749\&from=EN (downloaded 1702 2014)

[27] COUNCIL OF THE EUROPEAN UNION: Council Joint Action 2008/851/CFSP of 10 November 2008 on a European Union Military Operation to Contribute to the Deterrence, Prevention and Repression of Acts of Piracy and Armed Robbery off the Somali Coast. Official Journal of the European Union, L 301/33 (2008). http://eur-lex.europa.eu/legalcontent/EN/TXT/HTML/?uri=CELEX:32008E0851\&from=EN (downloaded 1702 2014)

[28] WISE, E. M., PODGOR, E. S., CLARK, R. S.: International Criminal Law: Cases and Materials. Second Edition, New York City: LexisNexis, 2004.

[29] SHAW, M. N.: Nemzetközi jog. Budapest: Complex Publisher, 2008.

[30] KOVÁCS P.: Nemzetközi közjog. Budapest: Osiris Publisher, 2011.

[31] Failed States Index IX2013. http://library.fundforpeace.org/library/cfsir1306failedstatesindex2013-061.pdf (downloaded: 0802 2014)

[33] WAGNER P.: A ,bukott államiság” és Afganisztán (Holtzer Lóránt emlékére). Kül-Világ, III 2 (2006), 37-54.

[34] JAMAL, A. R.: Identifying Causes of State failure: The Case of Somalia. Failed States in SubSaharan Africa. Konstanz: Universität Konstanz Politik- und Verwaltungswissenschaften, 2013. 